\title{
LAVERE STRAFF FOR MEDVIRKNING I RETTERGANGEN - PLEA BARGAINING
}

\section{Av førstestatsadvokat Harald Strand ${ }^{*}$}

Norwegian law offers criminal defendants two primary means for reducing their sentences through various forms of cooperation during the course of the proceedings. The first of these means is to plead guilty to all charges in court. Entry of a guilty plea will oblige the court to consider a reduction in sentence, a sentencing arrangement called 'reduction for guilty plea'. The determining factor in the court's assessment is the value of the guilty plea, or of any prior indication of a willingness to plead guilty. Calculation of this value is based on the plea's impact on closing the case, ameliorating the suffering of victims, or reducing the use of resources at the investigation, prosecution or trial stages. The second means by which a defendant might reduce his or her sentence is to assist in the investigation, e.g. by providing information on persons charged in the same or a different case, or by cooperating with the police in some other way. While the courts are not bound by prosecutorial requests for sentence reduction, a 2007 Supreme Court ruling states that the courts must be willing to attach a certain independent importance to undertakings by the prosecuting authority to request a reduced sentence. A stated condition, however, is that the contents of the request must conform to Supreme Court precedent. While the 'reduction for guilty plea' arrangement has a great deal in common with some types of 'plea bargaining', other types of plea bargaining are alien to Norwegian law and judicial precedent. Among them is the arrangement where the prosecuting authority will, in return for a guilty plea or admission of guilt, pursue a lesser charge than that supported by the available evidence.

\section{Innledning}

Dagens tema omfatter ulike former for siktedes medvirkning i rettergangen, og, vil jeg tilføye, like meget forut for rettergangen - under politiets etterforsking - og som i ulik grad resulterer i en mildere straffereaksjon.

For norske forhold skjer dette i hovedsak på to måter:

1) Ved at siktede i retten gir en uforbeholden tilståelse. I slike tilfelle skal retten ta dette i betraktning ved straffutmålingen, jf. straffeloven $\S 59$ annet ledd. Det innebærer at retten plikter å vurdere om tilståelsen skal føre til straffnedsettelse.

\footnotetext{
* Den muntlige form på innlegget i Nordisk Kriminalistmøte er beholdt i artikkelen.

* Title in English: Reduced Sentences as a Result of Cooperation during Legal Proceeding. Original in Norwegian.
} 
2) Ved at siktede på annen måte bidrar til å oppklare et straffbart forhold. Dette kan eksempelvis skje ved å gi opplysninger som gjelder andre siktede i samme sak eller i en annen sak eller ved annet samarbeid med politiet. Typisk er tilfellet med den arresterte narkotikakurer som i samarbeid med politiet fortsetter å opptre etter den forhåndsbestemte plan og derved hjelper politiet med å kunne pågripe andre involverte i den ulovlige innførselen.

Siktedes medvirkning kan også skje ved en kombinasjon - uforbeholden tilståelse om eget forhold og dertil gis det for eksempel opplysninger om medsiktede.

Innledningsvis kan det kanskje være grunn til å reflektere noe over den utvikling i straffeprosessen som vi ser blant annet $i$ Norge. Er den et utslag av at vi på en rekke samfunnsområder mer og mer er på vei inn i en markedstenkning? Står vi overfor utslag også på vårt område - strafferett og -prosess - av det samme fenomen som vi møter på så mange andre, nemlig mer marked, mindre offentlig styring? At borgeren også skal kunne forhandle med det offentlige om straff er kan hende en logisk videreføring av markedstanken? Mindre prinsipiell tenkning, mer økonomisk tilnærming? Er det tilfeldig at ordningen med plea bargaining er utviklet i markedets høyborg, USA? Vel, dette er spissformuleringer, og jeg overlater svaret til andre.

I og med at innlegget mitt tar for seg norske forhold, synes jeg også det er grunn til å understreke at Norge ikke er en isolert øy, og at den utviklingen vi har sett hos oss nok er et ledd i en utvikling vi ser i mange andre land. I et større perspektiv er nok det en utvikling som innebærer at påtalemyndigheten gis et større handlingsrom - fra legalitet til opportunitet - med større bruk av skjønn, og dermed mer makt og myndighet. Hvilke problemer kan det innebære? Også her nøyer jeg meg med å stille spørsmålet.

Rettsregler og rettspraksis av denne type - straffereduksjon for siktedes medvirkning i rettergangen - reiser uansett en rekke spørsmål, $f$ eks av mer overordnet kriminalpolitisk karakter. Og ikke minst rettssikkerhet for den siktede selv eller for andre siktede.

\section{Begrunnelsen for de norske regler om straffereduksjon}

Begrunnelsen for regler som belønner siktedes medvirkning i rettergangen vil ikke uten videre være hensynet til siktede selv, og i alle fall ikke bare det. To hovedhensyn har særlig vært trukket frem - det er prosessøkonomisk lønnsomt, og det tjener til oppklaring av forbrytelser, med andre ord dreier det seg om bedre metoder for bekjempelse av kriminalitet.

Straffesaker starter ikke i domstolene, og bevisene skaffes ikke til veie under rettergangen, men tidligere, under politiets etterforsking. Skal en oppnå betydelig prosessøkonomisk gevinst vil motivasjonen til å gi forklaring - tilståelse av eget el- 
ler andres forhold - regelmessig måtte være til stede - eller skapes - under politiets etterforsking/utredning. Det innebærer, slik jeg ser det, at regler eller praksis som medfører kompensasjon (redusert straff) for medvirkning til rettergangen forutsetter en form for interaksjon mellom på den ene side politi og påtalemyndighet og på den annen side, den siktede og hans forsvarer. Det bringer tanken inn på forhandlinger mellom parter om straff, noe som igjen leder til spørsmålet om hvordan domstolene bør stille seg til avtaler som påtalemyndigheten og den siktede har inngått - før rettergangen starter. Og hva med fornærmede, offeret for den straffbare handling?

Regelen om muligheten for strafferabatt ved uforbeholden tilståelse kom inn i norsk straffelov i 2001. Det er ikke nytt at såkalte tilståelsesaker har vært undergitt en forenklet rettergang etter norsk rett, med summarisk pådømmelse av en enedommer som i hovedsak på grunnlag av politiets saksdokumenter og siktedes forklaring for retten avsier dom. Også før regelen om tilståelsesrabatt ble tatt inn i straffeloven $\S 59$ annet ledd med virkning fra 2001 var det slik at en tilståelse ved straffutmålingen kunne anses som en formildende omstendighet. En begrensning lå, og ligger, i en regel om at slik forenklet rettergang ikke kunne anvendes i saker med strafferamme over 10 års fengsel.

Forut for lovendringen hadde en arbeidsgruppe nedsatt av Justisdepartementet pekt på at det nok i praksis ikke var særlig stor forskjell mellom den straff som ble idømt $i$ en tilståelsessak og den straff som ble ilagt etter en hovedforhandling med vanlig bevisførsel og der gjerningspersonen ikke hadde tilstått det straffbare forhold. Et av de spørsmål som reiste seg, var om dette kriminalpolitisk sett var heldig eller ikke.

En kom da til at tilståelser burde tillegges større vekt enn før. Det ble særlig lagt vekt på prosessøkonomiske hensyn, men også på hensynet til fornærmede. Om dette heter det i lovforarbeidene ${ }^{1}$ :

"Saker med uforbeholden tilståelse kan gjennomgående etterforskes raskere, billigere og på en mer hensynsfull måte enn de saker hvor skyldspørsmålet er omtvistet. Tilståelser leder dessuten til at flere saker blir oppklart. Dette er hensyn som etter departementets oppfatning må tillegges betydelig vekt i dagens strafferettspleie."

Om hensynet til fornærmede heter $\operatorname{det}^{2}$ :

"Også hensynet til offeret kan tilsi at en siktet som avgir uforbeholden tilståelse, bør få mil-
dere straff enn en siktet som ikke legger kortene på bordet. Særlig gjelder dette i sedelighets-
saker, fordi både etterforskingen og hovedforhandlingen er vesentlig mindre belastende for
fornærmede i tilståelsessaker. Blant annet unngår fornærmede å få sin troverdighet trukket
i tvil ... Også ved andre straffbare handlinger, f. eks. i voldssaker, kan påkjenningen for
fornærmede reduseres når gjerningspersonen tar ansvar for egen handling."

Særlig to mothensyn ble trukket frem under lovforarbeidet: 1) at straffenivået ville bli senket, og, 2) faren for at uskyldige personer erkjenner straffansvar fordi de 
ikke tar sjansen på å bli dømt uansett og da få en strengere reaksjon. Departementet understreket at risikoen for uriktige tilståelser er noe som må tas alvorlig, men viste også til at en tilståelse ikke automatisk vil føre til domfellelse, men at det avgjørende er om tilståelsen, sammenholdt med det som ellers foreligger av bevis i saken, er tilstrekkelig til å overbevise retten om den tiltaltes straffeskyld.

\section{Rettstilstanden}

Det overlates til rettens skjønn både om det skal gis rabatt i straffen og hvor stor denne skal være. Vurderingstemaet er i hovedsak hvilken betydning tilståelsen har hatt for sakens oppklaring, for fornærmede og for ressursbruken ved etterforsking, påtalebehandling og iretteføring. Det har i løpet av de siste 5-6 år utviklet seg en omfattende og til dels detaljert rettspraksis. Ytterpunktene for strafferabatten er klare: Det er stor forskjell på en uforbeholden tilståelse som kommer uoppfordret i første politiavhør, og en tilståelse som først foreligger under hovedforhandlingen etter at tiltalte innser at bevismaterialet mot ham er overveldende. Basert på en gjennomgang av Høyesteretts praksis til nå kan det legges til grunn at en straffereduksjon på ca 1/3 er korrekt der tilståelsen skal tillegges betydelig vekt, men også her kan det unntaksvis være aktuelt å gi større rabatt. I saker der tilståelsen ikke har hatt betydning for oppklaringen av saken - det forelå tilstrekkelige bevis fra før - men den likevel har forenklet etterforskingen og/eller iretteføringen, slik at strafferettsapparatet har spart tid og ressurser som kan frigjøres til andre saker, vil også tilståelsesrabatt være aktuell.

I den såkalte NOKAS-saken, som gjaldt et væpnet ran gjennomført nærmest som et militært kommandoraid der en politimann ble drept og ransutbyttet ble 57 millioner kroner, heter det i Høyesteretts dom av 29. juni $2007^{3}$ :

\footnotetext{
"Mange av de som har tilstått i NOKAS-saken, har tilstått sent i saksforløpet, etter å ha tatt inn over seg at bevisene mot dem var sterke. Flere av dem prøvde først ut andre forklaringer og noen også falske alibier. Den prosessøkonomiske betydningen av disse tilståelsene er svært begrenset. Hensynet til de fornærmede og i noen grad til verdien av å ta ansvar for sine handlinger, kan derimot begrunne strafferabatt også for slike tilståelser."
}

Straffereduksjon for bistand til politiet under etterforskingen eller for å ha forklart seg om andre siktede - i egen eller i annen sak - er ikke lovregulert. Det er overlatt til domstolene å avgjøre hvilken betydning samarbeid med politiet skal få for straffutmålingen, og det har utviklet seg en helt klar rettspraksis på at det kan gis straffereduksjon, til dels betydelig straffereduksjon, for ulike former for bistand til politiet. Jeg sa at vi ikke har lovfestet regler om dette i Norge. Tvert i mot, da Justisdepartementet la frem for Stortinget forslag til reglene om tilståelsesrabatt, valgte departementet helt bevisst ikke å ville lovregulere spørsmålet om straffereduksjon for bl a samarbeid med politiet. Departementet viste særlig 
til $^{4}$ at det lett vil kunne oppstå tvil om siktedes forklaring er sannferdig eller ikke fordi siktede i slike situasjoner, i motsetning til ved tilståelser, har lite å tape på å gi opplysningene. Etter departementets syn kunne det dessuten være prinsipielt betenkelig å lovfeste regler som oppfordrer til angiveri, og som øker risikoen for at siktede blir utsatt for represalier. Departementet var fullt klar over den rettspraksis som forelå. Med andre ord, man valgte i Norge å lovfeste det lette og lukke øynene for det vanskelige.

Plea bargaining er også angitt som tittel på innlegget mitt. Dette omfatter etter det jeg forstår ulike former for avtaler mellom siktede og påtalemyndigheten der siktede gis fordeler mot å avgi tilståelse eller erkjenne straffeskyld. En variant er den ordning der påtalemyndigheten etter avtale legger ned lavere straffepåstand for domstolen som motytelse for at siktede tilstår etter siktelsen. I prinsippet antar jeg dette har atskillig til felles med det norske systemet med strafferabatt etter straffeloven $\S 59$ annet ledd.

Andre former for plea bargaining er i utgangspunktet fremmed i norsk rett eller rettspraksis. Dette gjelder f eks ordninger der påtalemyndigheten tar ut siktelse for et mindre alvorlig straffebud enn den mener den kan føre bevis for mot at siktede tilstår eller erkjenner straffeskyld for dette mindre alvorlige forhold. Riksadvokaten har klart og tydelig sagt fra at han $i k k e$ godtar avtaler mellom siktede og påtalemyndigheten om hvilke forhold som skal strafforfølges. Riksadvokaten har også instruert om at henleggelse eller nedsubsumering ikke skal brukes som vederlag ("betaling") for opplysninger.

Når siktede har avlagt en uforbeholden tilståelse, saken ikke gjelder en forbrytelse med høyere strafferamme enn 10 års fengsel og han samtykker, kan det avsies dom etter en forenklet rettergang - uten hovedforhandling - basert på siktedes forklaring og sakens dokumenter, forutsatt at retten finner det ubetenkelig. Dette er den ene typiske arenaen for tilståelsesrabatt etter norsk rett. Den andre arenaen er hovedforhandlingen, enten fordi forbrytelsen har for høy strafferamme til forenklet rettergang, og da gjerne en hovedforhandling med begrenset bevistilbud. Eller en hovedforhandling med flere involverte hvorav noen har tilstått, andre ikke, og påtalemyndigheten ikke skiller ut saken mot den som har tilstått, til egen behandling. For begge tilfeller minner jeg om at påtalemyndigheten når den "skjærer til" en sak for domstolen som et utslag av opportunitetsprinsippet etter en prosessøkonomisk vurdering kan henlegge forhold som ikke er tilstått. Lovens krav er at ingen eller bare en ubetydelig (mer)straff ville komme til anvendelse dersom slike forhold ble tatt med i saken.

\section{Utfordringer}

Ordningen innebærer en rekke utfordringer for påtalemyndigheten. Et eksempel er tydelig å avgrense mot politimetoder som krenker mistenktes eller siktedes 
rett til en rettferdig rettergang. Etter straffeprosessloven $\S 93$ annet ledd er det forbudt å bruke løfter/lovnader som metode under avhør. På den annen side er det slik, som uttalt av Høyesterett ${ }^{5}$, at ordningen med strafferabatt "innebærer rimeligvis at en siktet $\mathrm{i}$ mange tilfeller på forhånd kan føle behov for nærmere kunnskap om de strafferettslige konsekvensene av å tilstå", og det er som også uttrykt av Høyesterett i samme sak "ikke uvanlig at slike spørsmål - de strafferettslige konsekvensene av å tilstå - blir drøftet mellom siktede/forsvareren og påtalemyndigheten." Det kan tilføyes at det lett blir et spill om ord om en kaller dette drøftelser eller forhandlinger.

Det kan oppstå spørsmål om bevisførsel i forbindelse med tilbud eller krav om tilståelsesrabatt, enten fra påtalemyndighetens side eller fra forsvareren. Siktede har for eksempel tilstått overfor etterforskeren, men fragår dette, fordi vedkommende mener rabatten er for liten. Det kan da være aktuelt for påtalemyndigheten å føre etterforskeren som vitne. Forsvareren kan på sin side hevde at tiltalte er forespeilet en større rabatt $\mathrm{g}$ vil føre etterforskeren eller politijuristen som vitne for å underbygge dette. Denne type informasjon kan etter riksadvokatens syn etter omstendighetene ha "betydning for saken", jf. straffeprosessloven $\S 292$ annet ledd. I så fall kan beviset ikke avskjæres og etterforskeren har forklaringsplikt og sannhetsplikt som vitne. Noe prinsipp om at "forliksforhandlinger gis det ikke opplysninger om hvis forlik ikke oppnås" eller lignende, slik en kjenner det fra sivilprosessen, er det således ikke rom for i straffesaker.

Riksadvokaten har i mai i år utgitt et rundskriv om tilståelsesrabatt. Det er tilgjengelig på vår hjemmeside www.riksadvokaten.no

Her gis det retningslinjer for politiets og påtalemyndighetens saksbehandling, det stilles blant annet krav til notoritet, skriftlighet og åpenhet. Et av formålene med rundskrivet er å sikre at påtalemyndigheten legger til rette for at bestemmelsen om straffereduksjon ved uforbeholden tilståelse får den effekt som lovgiveren har tilsiktet. De detaljerte regler for hvordan politiet skal gi informasjon om ordningen er også ment å hindre misbruk av siktedes rettigheter under avhør.

I rundskrivet oppstilles tre vilkår som må være oppfylt ved bruk av forhånd stilsagn om straffepåstand:

- Det må klargjøres overfor siktede at domstolene er ubundet av påtalemyndighetens straffepåstand.

- Det må være tilstrekkelig klart hvilke straffbare forhold (art og omfang) tilsagnet knytter seg til.

- Tilsagnet må gis av påtalemyndigheten (ikke etterforsker).

Ellers tillater ikke tiden at jeg kommer nærmere inn på rundskrivet her. 


\section{Forutberegnelighet}

En av flere forutsetninger for at ordningen med strafferabatt skal få den forventede prosessøkonomiske virkning er klarligvis at den er forutberegnelig.

Det vil den bare være dersom tilsagnet fra påtalemyndighet om en bestemt straffepåstand er sammenfallende, eller tilnærmet sammenfallende, med den straff domstolen utmåler.

Hvordan stiller så domstolene seg til avtaler mellom påtalemyndigheten og siktede om størrelsen på straffepåstanden? 24. april i år behandlet Høyesterett ${ }^{6}$ dette spørsmålet. Det gjaldt en ankesak for lagmannsretten der påtalemyndigheten inngikk avtale med flere siktede om at påtalemyndigheten skulle nedlegge en bestemt - og lavere - påstand dersom de siktede trakk sin anke over skyldspørsmålet. Et flertall i Høyesterett (3 mot 2 dommere) uttalte blant annet:

\footnotetext{
"Gode grunner kan etter omstendighetene tale for at påtalemyndigheten inngår denne type avtaler for på den måten å begrense rettsforhandlingene ... Skal formålet kunne oppnås, må det være en viss forutberegnelighet med hensyn til hvilket gjennomslag påtalemyndigheten vil kunne få i domstolen. Dette tilsier at domstolen må vare villig til å tillegge slike utsagn en viss selvstendig betydning... Forutsetningen er selvfølgelig at påtalemyndigheten ved inngåelsen av slike avtaler opptrer lojalt i forhold til de retningslinjer for strafferabatt som er trukket opp i Høyesteretts praksis."
}

Det var skarp dissens i Høyesterett. Mindretallet på 2 dommere uttalte blant annet at et system der påtalemyndigheten forhandler om lavere straffepåstand som motytelse til at tiltalte tilstår ikke har hatt noen plass i norsk straffeprosess. Tvert imot, sa mindretallet, har forhandlinger etter mønster av amerikansk "plea bargaining" vært oppfattet å være i strid med norske rettsprinsipper.

Tiden får vise om siste ord er sagt, men rettstilstanden pr i dag er i hvert fall at domstolene må tillegge tilsagn om strafferabatt en viss selvstendig betydning.

Jeg nevner i denne sammenheng at Justisdepartementet i et høringsnotat fra september 2006 har foreslått en regel om bindende straffetilsagn som medfører at domstolen ikke kan idømme strengere straff enn den påstand påtalemyndigheten har forpliktet seg til, med mindre straffen ville innebære et vesentlig avvik fra det som ellers ville blitt idømt. Høyesterett har på prinsipielt grunnlag gått mot forslaget. Heller ikke riksadvokaten støtter det. Det vil være overraskende om departementet går videre med dette lovforslaget.

\section{Nytteverdi}

Har ordningen med strafferabatt ved tilståelser vært noen suksess? Det har nok vært en forventning om at ordningen med tilståelsesrabatt skulle gi prosessøkonomisk gevinst for strafforfølgningen av den såkalte hverdagskriminaliteten (vinningssakene). Volummessig har imidlertid ikke innføringen av strafferabatt med- 
ført nevneverdige endringer. Det er ikke mulig til nå å konstatere noen økning i antallet tilståelsesdommer sett $\mathrm{i}$ forhold til antallet meddomsrettssaker (ordinære hovedforhandlinger). Min oppfatning er at ordningen hittil først og fremst har vært, og er, et sentralt virkemiddel i bekjempelsen av den alvorlige, organiserte kriminaliteten, og da gjerne i sammenheng med rettspraksis som gir redusert straff for den som på annen måte enn tilståelse av eget forhold bidrar til å oppklare kriminalitet. Også for store økonomiske straffesaker som ikke defineres som organisert kriminalitet anser jeg tilståelsesrabatt som et egnet og effektivt virkemiddel både materielt (oppklaring) og prosessuelt (ressursbesparelse).

Da avslutter jeg med en snarvisitt til denne form for medvirkning i rettergangen.

\section{Annet samarbeid med politiet}

Etter norsk straffutmålingspraksis kan det gis straffereduksjon for samarbeid med politiet om oppklaring av saken - f eks ved å forklare seg om medsiktedes forhold. Særlig aktuelt er dette i narkotikasaker og ved annen organisert eller grenseoverskridende kriminalitet. En siktet som har forklart seg om andres forhold, kan i slike saker lett utsette seg for fare eller hevnaksjoner.

Det var tidligere ikke tradisjon for at det i slike tilfeller foregikk drøftelser mellom påtalemyndigheten og siktede eller hans forsvarer om betydningen av samarbeidet for straffepåstanden. Politiet kunne likevel i slike tilfelle orientere om den rettspraksis som forelå, men uten at det ble inngått konkrete avtaler om påtalemyndighetens påstand for domstolen. I og med at samarbeid med politiet ikke sjelden inntrer i kombinasjon med tilståelse av eget forhold er situasjonen i dag at også betydningen av samarbeid kommer opp i drøftelser om tilståelsesrabatt.

Et spørsmål er hvorledes dette moment til straffutmålingen skal kunne opplyses overfor domstolen.

Høyesterett har i en avgjørelse i Rt. 1995 side 1975 uttalt følgende:

\footnotetext{
"Etter min oppfatning må det aksepteres at det legges vekt på politiets behov for bistand fra siktede og på siktedes behov for beskyttelse. For å imøtekomme disse behov må det aksepteres at aktor i forholdsvis generell form gir domstolen opplysninger om at domfelte har ytet bistand til etterforskingen og om den større eller mindre betydning bistanden har hatt. Det bør ikke stilles krav om at aktor skal gå inn på enkeltheter og heller ikke at opplysningene skal underbygges bevismessig ..."
}

Så sent som i behandlingen av den såkalte NOKAS-saken, jf. foran, viste Høyesterett til denne tidligere uttalelsen da den ga en av de domfelte en betydelig straffereduksjon i form av betinget reaksjon. Fengselsstraffene for de fleste invol- 
verte varierte i hovedsak fra 11 til 18 års fengsel. Høyesterett idømte den aktuelle domfelte en straff av fengsel i 4 år, hvorav $3 \frac{1}{2}$ år ble gjort betinget. Det sies i dommen:

"N samarbeidet også med politiet under oppklaringen av NOKAS-saken. Dette har åpenbart vært av stor betydning. Det er ikke opplyst hva N nærmere har forklart, men Riksadvokaten har bekreftet at de opplysninger $\mathrm{N}$ har gitt, var viktige på den tiden de ble gitt. Han har også nedlagt den samme påstand som Ns forsvarer ...

På denne bakgrunn (henvisning til avgjørelsen i Rt. 1995 side 1975) tar jeg til etterretning Riksadvokatens uttalelse om betydningen av Ns samarbeid med politiet og finner ikke grunnlag for å overprøve hans vurdering her."

Avgjørelsen gjaldt domfelte nr. 14 i en meget alvorlig sak, og kom selvfølgelig i skyggen av de andre domfellelsene i saken, med meget lange straffer. Den har derfor vakt liten oppmerksomhet.

Høyesterett er beskjeden på egne vegne når den uttaler at den ikke finne grunnlag for å overprøve riksadvokaten. I og med at Høyesterett gir betydelig straffreduksjon for bistand til sakens oppklaring uten å ha kunnskap om hva bistanden har gått ut på, foretar vår høyeste domstol ikke noen form for prøving eller kontroll av påtalemyndighetens vurderinger. Det er et eksempel på en av flere problemstillinger ved at påtalemyndigheten gis stor makt og myndighet $\mathrm{i}$ utøvelsen av sitt skjønn - stort handlingsrom - og uten innsyn for domstolen. Det er et ikke ubetydelig ansvar å forvalte denne myndigheten og ivareta hensyn til $\mathrm{f}$ eks likebehandling av både ressurssvake og ressurssterke siktede.

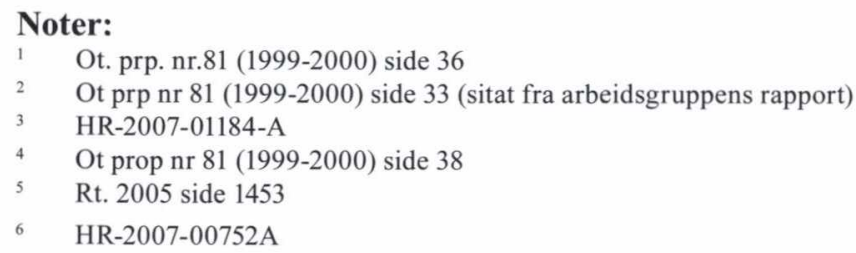

Adresse:

Riksadvokaten i Norge

Postboks 8002 Dep

NO - 0030 Oslo 